\title{
Development and Evaluation of Portal do Zumbido: A Novel Telehealth Approach to Tinnitus
}

\author{
Izabella Lima de Matos $^{1}$ (1) Maria Carolina Ferreira ${ }^{10}$
}

Maria Fernanda Capoani Garcia Mondelli ${ }^{1}$ (1)

Address for correspondence Maria Carolina Ferreira, Programa de Fonoaudiologia, Faculdade de Odontologia de Bauru (FOB), Universidade de São Paulo (USP) Alameda Doutor Octávio Pinheiro Brisolla, 6-65, Jd. Pagani, Edifice Tapajós, Apartment 51, Bauru, São Paulo, 17012059, Brazil (e-mail: mariaferreira@usp.br).

\begin{abstract}
Introduction Tinnitus is a prevalent symptom in audiological clinics, and the speech therapist participates in the assessment, diagnosis, and intervention of tinnitus. A range of studies have been developed with the aim to promote auditory health, and telehealth is an option for this purpose.

Objective The aim of the present study was to develop and assess a virtual platform for tinnitus management for speech therapists.

Methods The present study provided a distance-learning-course, with the aid of Portal do Zumbido, available in the following electronic address: zumbido.fob.usp.br. Infographics were available for download, and modules were made to comprise the introduction to the symptoms, assessment, and intervention for tinnitus.

Results Speech therapists of different regions of Brazil received an e-mail invitation to participate and to assess the platform, 46 of whom registered. From the 46 speech therapists registered, 38 assessed the virtual platform with the aid of a questionnaire about the theoretical content and then answered a motivational research sheet (MRS). The speech therapists correctly answered $90 \%$ and $100 \%$ of the questions in the questionnaire and in the MRS, respectively, which may indicate that the professionals positively absorbed the content; thus, the content was considered to be impressive

Keywords

- telemedicine

- tinnitus

- hearing aids when the MRS was analyzed.

Conclusion Portal do Zumbido was developed and is available for access in the following electronic address: zumbido.fob.usp.br. Furthermore, the platform received a positive assessment by the speech therapists who participated in the present study.
\end{abstract}

\section{Introduction}

Tinnitus is a symptom characterized as the perception of a sound in the ears or in the head without an external sound stimulus. It can occur unilaterally or bilaterally and classification varies according to the duration, so that it is classified as acute when it occurs for less than 6 months, or chronic when it occurs for 6 months or longer. The preva-

received

September 23, 2019

accepted

DOI https://doi.org/ 10.1055/s-0040-1709113. ISSN 1809-9777.

February 11, 2020

published online

June 30,2020 lence of the symptom is 10 to $15 \%$, and it is higher among the elderly. ${ }^{1}$

This auditory complaint can be associated with quality of life impairments, such as decreased social interaction, insomnia, emotional and general health changes as well as problems at work. ${ }^{2}$ Furthermore, tinnitus management can attach a high cost to health services because it is not standardized. ${ }^{3,4}$

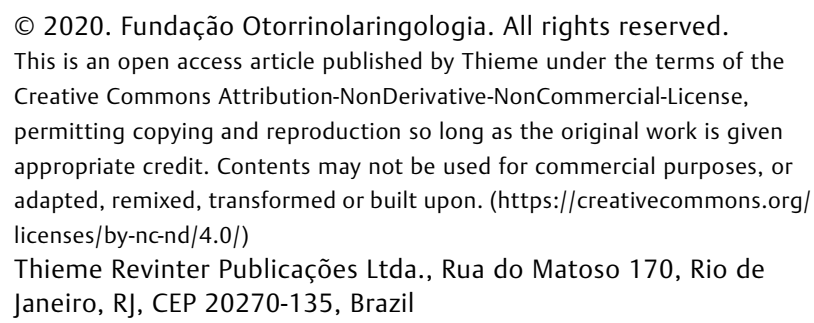

(c) 2020. Fundação Otorrinolaringologia. All rights reserved.

This is an open access article published by Thieme under the terms of the Creative Commons Attribution-NonDerivative-NonCommercial-License, permitting copying and reproduction so long as the original work is given appropriate credit. Contents may not be used for commercial purposes, or adapted, remixed, transformed or built upon. (https://creativecommons.org/ licenses/by-nc-nd/4.0/) Thieme Revinter Publicações Ltda., Rua do Matoso 170, Rio de Janeiro, RJ, CEP 20270-135, Brazil 
The subjects with tinnitus complaints often search for hearing health services, and this has generated a growing search for the evaluation, diagnosis, and effective treatment of the symptom. Thus, recent studies have been developed with the aim of helping professionals who attend patients with tinnitus at their clinics for symptom management. ${ }^{5,6}$

The etiological diagnosis is important, and, due to the multifactorial etiology of tinnitus, an audiologist is required from the assessment to the intervention of the symptom. ${ }^{7,8}$ Due to this concern, several studies have been developed with the purpose of hearing health promotion. However, there is an irregular and insufficient distribution of public health services, educational institutions and qualified professionals, leading to the difficulties of access to specialized services. Due to the current condition, telehealth can be a significant alternative at this time. ${ }^{9}$

In the context of an irregular distribution of health professionals, shortage of services that promote the training of professionals in this area, and current technological advances, telehealth emerges as an important alternative for the use of teleassistance resources (health care alternatives) and tele-education (distance education), since it allows the reduction of costs and resources needed, as well as facilitates the quickly professional-patient relationship. ${ }^{10,11}$

Telehealth is the transferring of health information between distant places, and it includes a range of activities beyond patient care, such as health promotion, epidemiological surveillance, disease prevention, patient and professional education, and health service management. ${ }^{9}$ Systematic actions are required to plan and develop new teaching strategies and methods that incorporate the teaching-learning process into information and communication technologies, especially the internet. ${ }^{12}$

Due to the wide geographic dimensions of Brazil, there is a heterogeneity in the distribution of speech therapists. Thus, telehealth is an option for the specialized knowledge decentralization of health professionals. ${ }^{13}$ Therefore, the present study aims to develop and assess a virtual platform on tinnitus management to provide scientific technical access for speech therapists.

\section{Materials and Methods}

The study was developed in the Speech Therapy Program at Faculdade de Odontologia de Bauru - Universidade de São Paulo, with the approval of the Research Ethics Committee (CEP) of this institution (number 88446218. 2.0000.5417).

\section{Development of a Virtual Learning Platform}

A proposal was made to conduct the distance-learning course (tele-education) through the internet, using a virtual management platform of tinnitus in subjects with and without hearing impairment entitled "Portal do Zumbido", which is available at the following electronic address: zumbido.fob.usp.br. It is important to note that although the platform was initially designed to provide necessary information to professionals who attend patients with audi- tory impairments (tinnitus/hearing loss), it can be accessed by any professional who has interest to require information about the symptom, diagnosis, evaluation, and treatment.

To incorporate real teaching-learning situations and use the potential of the internet, the development of the content of the platform used information design and infographicsas facilitating resources.

Information design is a facilitating agent in the selection, structuring, and information organization of complex systems. ${ }^{14}$ Together with web design, it provides information that the interpreter needs for specific tasks based on the interaction between verbal and visual communication. Information design is based on helping people with different experiences. $^{15}$

The infographics, in turn, were used as tools for visual representations of informational character, since they have a high power of attraction, combining text and image to reveal more clearly and simplify complex information, saving space. ${ }^{16,17}$

\section{Content Covered in the Virtual Platform}

The main contents were selected to provide theoretical knowledge for speech therapists regarding tinnitus management (-Fig. 1). All the content of the Portal do Zumbido was developed and was available for download and printing. The portal is comprised of the following modules:

\section{Tinnitus:}

This is the first module of the Portal do Zumbido, and it introduces the subjects to the symptom, with questions such as "What is it?", "How does it manifest?", and "Is there a cure?."

\section{Audiological Diagnosis:}

This module discusses the importance of a well conducted audiological diagnosis, and it explains how to perform the following procedures: "inspection of the external acoustic meatus (EAM)," "pure-tone audiometry," "tympanometry" and "acoustic reflex testing."

\section{Further Examinations:}

Further procedures are described in this module, such as "high frequency audiometry (HFA)," "minimum masking level (MML)," "psychoacoustic measures (pitch and loudness matching)," "transient otoacoustic emissions and distortion product"

\section{Fitting of hearing aids:}

This module is about the indication of hearing aids use in subjects with tinnitus complaints; what kinds of therapy the hearing aid is used for;and it presents the essential aspects of correct hearing aid fitting and selection.

\section{Fitting of a sound generator (SG):}

This module covers the main issues involving a SG, and it explains what these devices are, why they are used in patients with tinnitus, the noise used and measurements. 


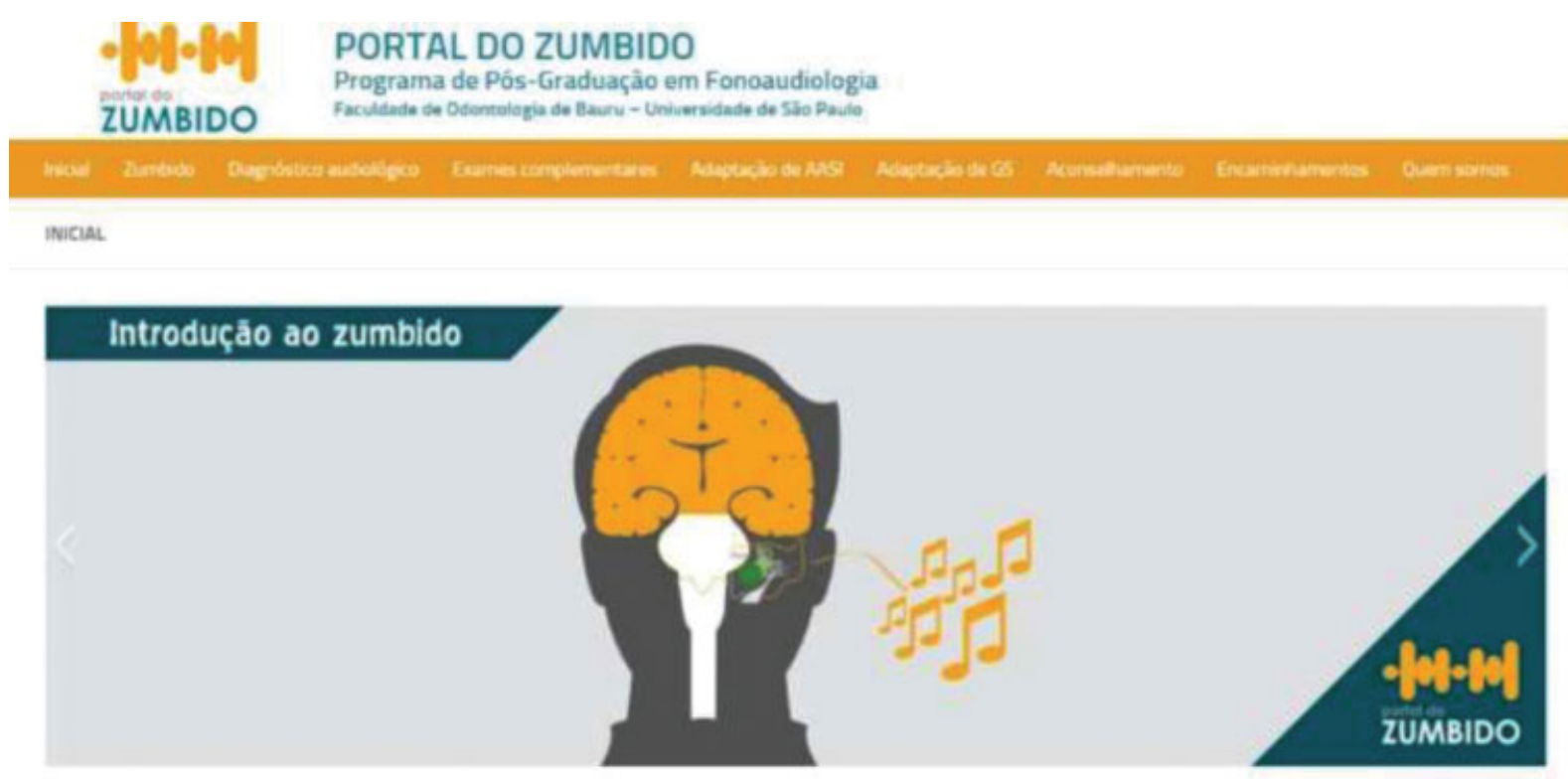

Fig. 1 Homepage of Portal do Zumbido.

\section{Counseling:}

This module describes, with the aid of available didactic material concerning the topic, how counseling is used as an intervention in patients with tinnitus.

\section{Leading:}

The present module is about the importance of guiding patients with tinnitus to other specialties, as well as information regarding the professionals involved in the symptom evaluation and intervention process.

\section{Who we are:}

Tinnitus is a topic studied by several Speech Therapy Program students, guided by Prof. Dr. Mondelli, MFCG. This topic introduces the team that studies the symptom in Faculdade de Odontologia de Bauru - Universidade de São Paulo.

\section{Assessment:}

This module is composed of theoretical content and personal data, available download of informed consent form and the motivational research sheet (MRS).

The following questionnaires (module access "fitting of hearing aids") were available for download and printing: Hearing Handicap Inventory for Adult (HHIA), Hearing Handicap Inventory for Elderly (HHIE), and Tinnitus Handicap Inventory (THI).

In addition, didactic material for download and printing, entitled "Manual do Zumbido" (access module "Counseling"), was available.

For viewing in PDF and downloading the contents of all modules, access zumbido.fob.usp.br.

\section{Assessment of the Portal do Zumbido}

1. Subjects
Speech therapists working in the five regions of the country were invited to participate in the present study. Access to the platform was proposed with theoretical content on tinnitus management (tele-education) through Portal do Zumbido, available at the zumbido.fob.usp.br electronic address.

The contact was conducted by e-mail, in which the professionals were guided and informed about the objectives of the present study.

Professionals were guided to register at Portal do Zumbido informing their personal data (name, e-mail, ID, registration number in the Federal Council of Speech Therapy, region of work, and academic level). All participants were informed regarding the purpose and procedures of the study and the need to agree to the informed consent form that was available online and for download.

\section{Questionnaire about the theoretical content}

The professionals were guided to access the portal and, at the end, to answer an online form (Appendix A) in the module "assessment." This form was prepared using the Google Forms tool, and it was composed of 10 questions regarding the content of Portal do Zumbido. Each question had three answer options, out of which only one was correct. If the participant hit the correct answer, he or she got 1 point and, if the participant failed, he or she did not score. At the end of the questionnaire, the professionals received feedback on their performance.

The e-mail portalzumbido@gmail.com was available to answer the questions of the participants.

\section{Motivational Research Sheet (MRS)}

After accessing the modules, the MRS was used for the assessment of motivational aspects related to Portal do Zumbido. ${ }^{10,18}$ The MRS is composed of 32 statements. Numerically, each statement is punctuated as follows: (3) completely agree, (2) partially agree, (1) partially disagree, and $(0)$ completely disagree. 
The MRS statements are grouped into four domains: "stimulant," "significant," "organized," and "easy to use." The domain "stimulant" is grouped by statements $1,5,9$, $13,17,21,25$ and 29 . The domain "significant" by statements $2,6,10,14,18,22,26$ and 30 . The domain "organized" by statements $3,7,11,15,19,23,27$ and 31 . The "easy to use" domain by statements 4, 8, 12, 16, 20, 24, 28 and 32 .

After scoring each domain individually, they are grouped according to the formula: $\mathrm{V}=\mathrm{E}+\mathrm{S} ; \mathrm{XS}=\mathrm{O}+\mathrm{F}$. The V score is the sum of the domains "stimulant" and "significant" and reflects the value dimension, that is, how valuable this distance-learning-course is. The XS score is the sum of the "organized" and "easy to use" domains and reflects the expectation dimension for success. To finalize the score, the WebMAC authors recommended the use of a Cartesian projection. The abscissa (X-axis) is the score corresponding to the value dimension, and the ordinate (Y-axis) is the score corresponding to the expectation dimension for success. If the points or a large number of individual points are located within the area (impressive course!), it means that the distance-learning-course is an "impressive course," evaluating it positively. ${ }^{18}$

\section{Data Analysis}

The data collected through the questionnaires were transferred to a Microsoft Excel (Microsoft Corp., Redmond, WA, USA) spreadsheet and analyzed through quantitative and qualitative descriptive statistics.

\section{Results}

Speech therapists who worked in five regions of the country were invited to participate in the present study. Forty-six professionals (-Fig. 2) registered but only 38 answered the entire questionnaire (-Fig. $\mathbf{3}$ ).

\section{Questionnaire about the Theoretical Content}

After the participants read all of the modules, they were instructed to answer 10 questions about the theoretical content (Appendix A) to verify how much information from the content covered in the Portal do Zumbido they absorbed (-Fig. 4).

\section{Motivational Research Sheet - MRS}

-Table 1 presents the descriptive statistical analysis by domain assessed by the participants on the MRS.

Below are the MRS results presented in the form of Cartesian projection (-Fig. 5), demonstrating the expectation for the success of the elaborated program.

\section{Discussion}

Tinnitus is considered a public health issue due to its prevalence and all the negative changes that may be associated with it. As such, studies have been developed to help the professionals in the assistance of this population. ${ }^{19,20}$ Therefore, the present study used tele-education to provide information based on scientific evidence for speech therapists.

Speech therapists of three different regions of Brazil participated in the present study (-Fig. 3), which characterized the internet and the advanced technology as facilitating resources for the transmission of information. ${ }^{21}$ The region with the highest number of professionals participating in the present study was the Southeast. This result can be explained when analyzing the speech therapists' division in Brazil, which presents a high concentration of these professionals in the Southeast region, of which 12,577 are in the state of São Paulo. ${ }^{22}$ Thus, the Speech Therapy Program of Faculdade de Odontologia de Bauru - Universidade de São Paulo is considered the pioneer in the creation and development of educational tools using tele-education in audiology as well as

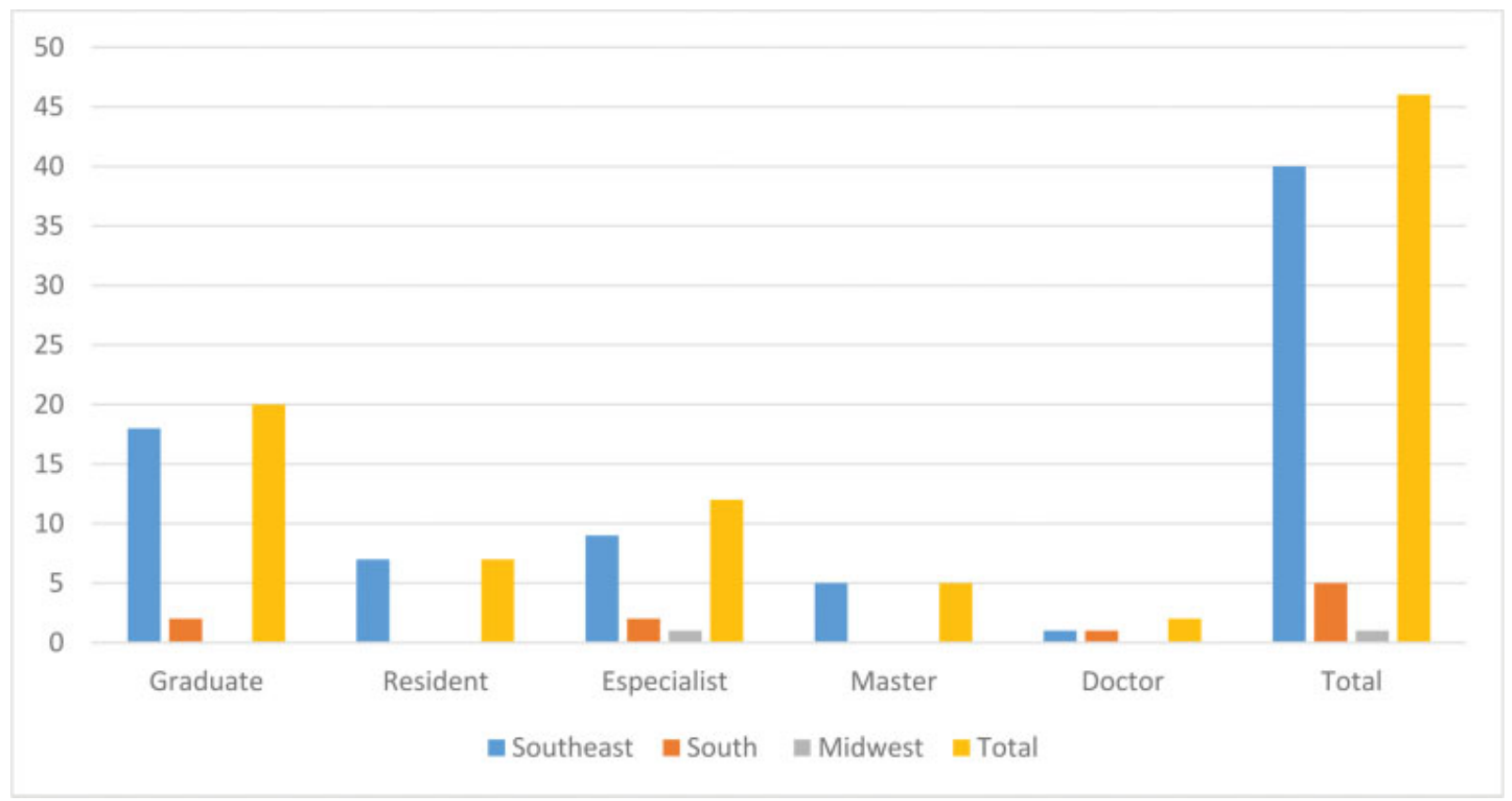

Fig. 2 Graph of the regions and academic level of speech therapists registered in the Portal do Zumbido $(n=46)$. 


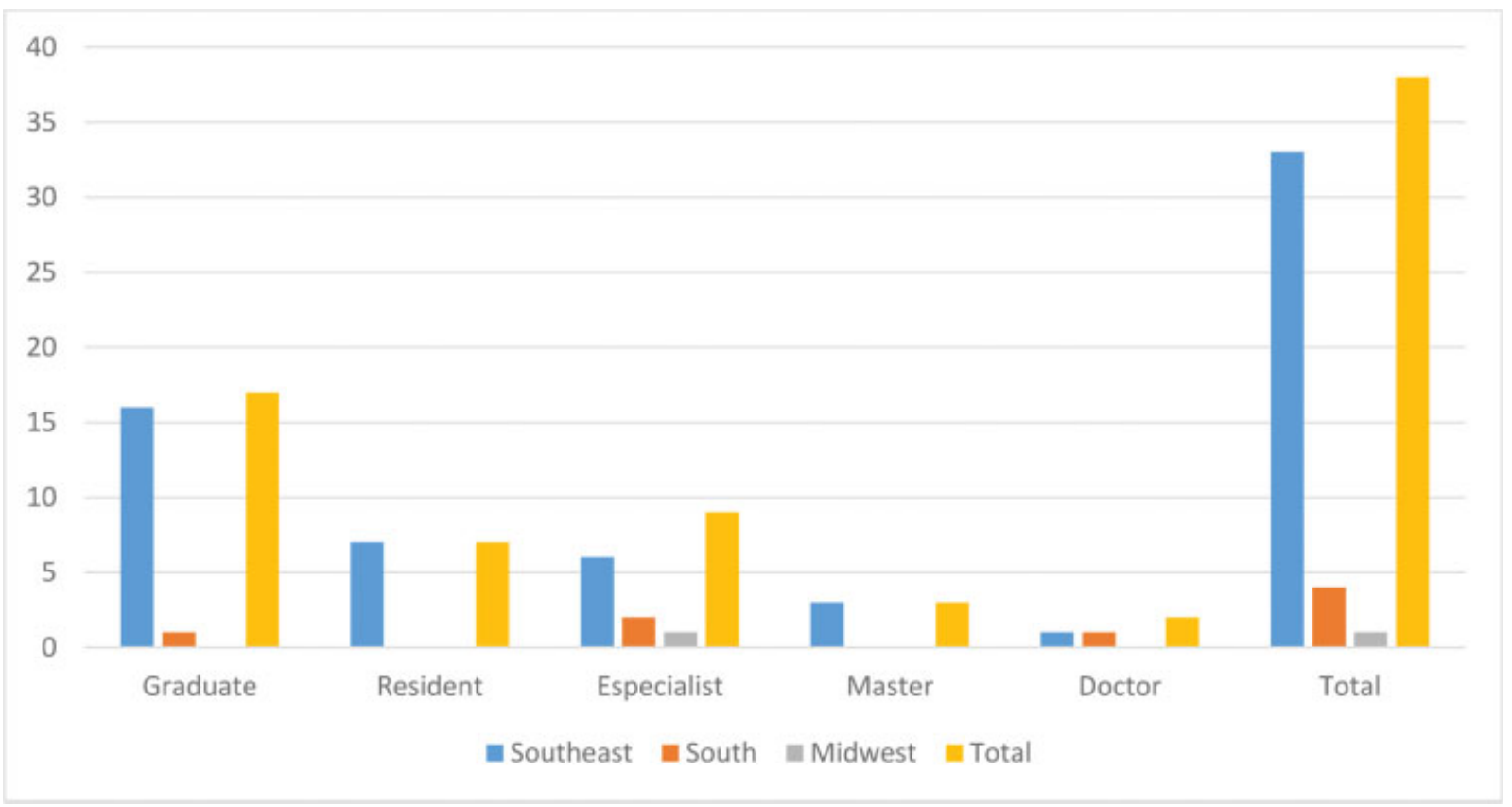

Fig. 3 Graph of the regions and academic level of speech therapists who answered the entire questionnaire $(n=38)$.

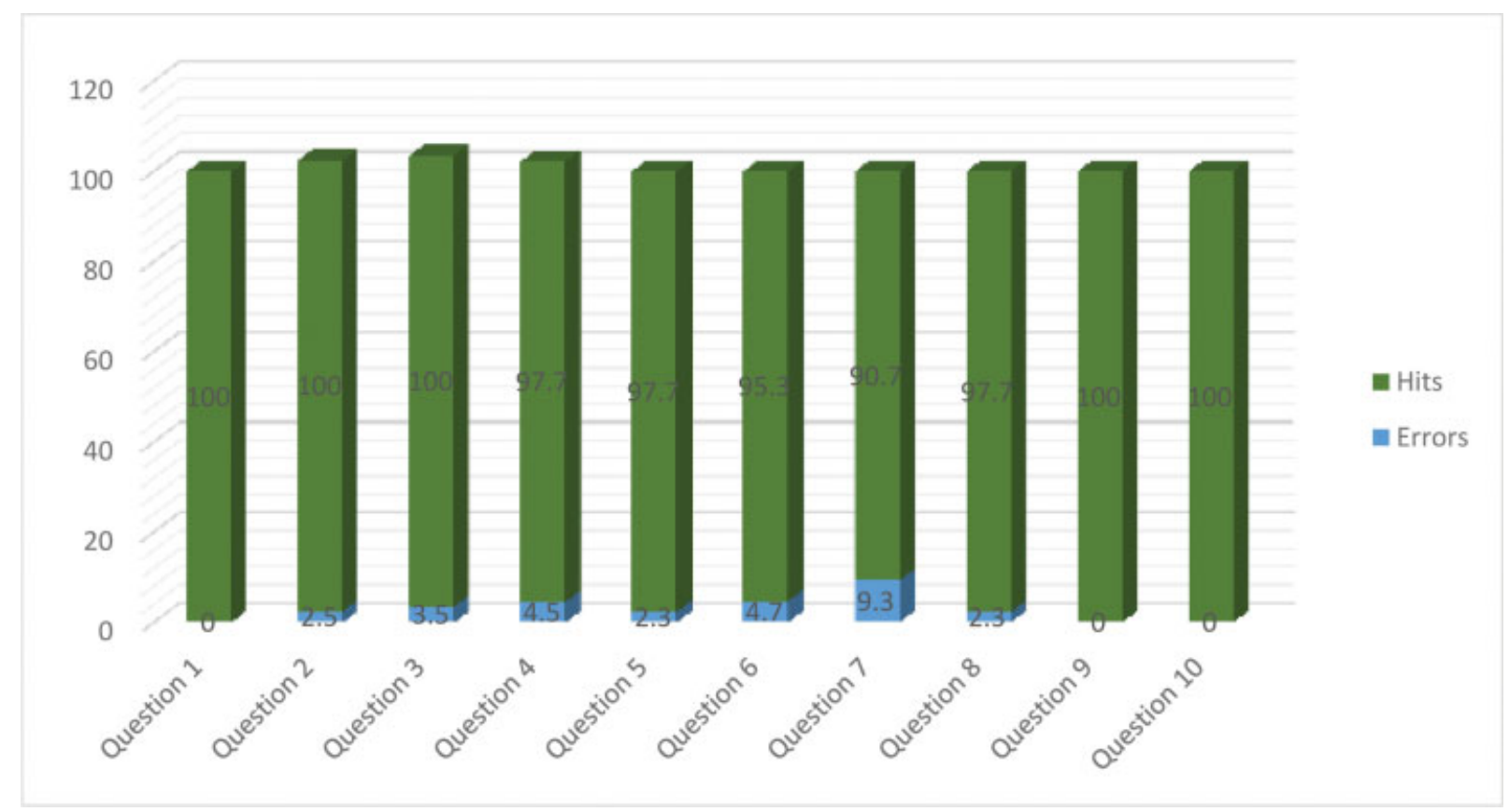

Fig. 4 Distribution of percentage of correct and incorrect answers of the sample according to the questionnaire on the theoretical content $(n=38)$.

Table 1 Descriptive statistical analysis by domain assessed by the participants who filled out the motivational research sheet

\begin{tabular}{|c|c|c|c|c|c|}
\hline DOMAIN & Mean & Median & Minimum & Maximum & SD \\
\hline Stimulant & 22.8 & 24 & 19 & 24 & 1.6 \\
\hline Significant & 22.4 & 23 & 15 & 24 & 2.0 \\
\hline Organized & 22.5 & 23 & 16 & 24 & 2.1 \\
\hline Easy to use & 22.2 & 23 & 16 & 24 & 2.1 \\
\hline
\end{tabular}

Abbreviation: SD, standard deviation. 


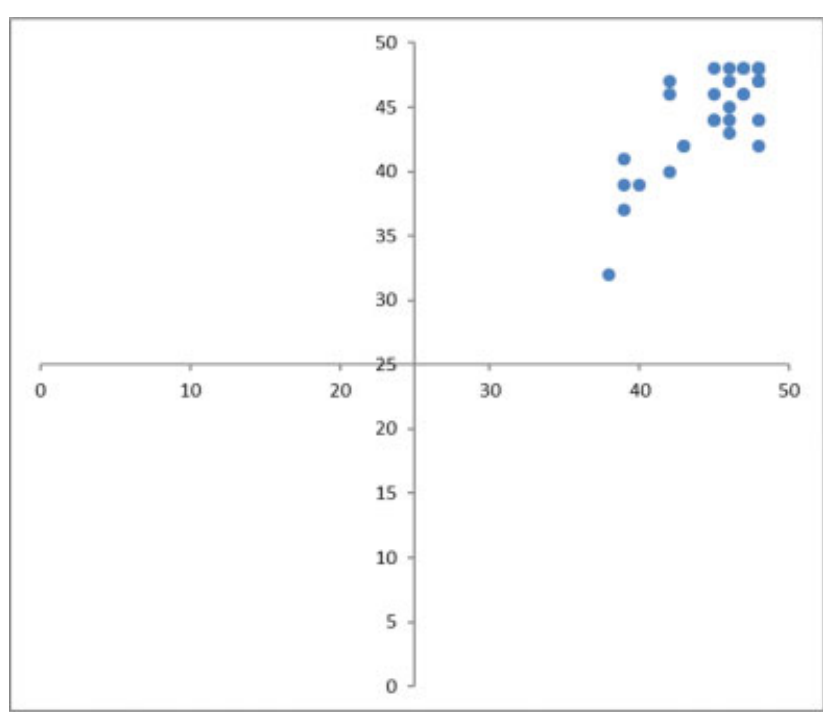

Fig. 5 Classification of the Portal do Zumbido distance-learningcourse.

offering great support to studies that involve technology in the teaching-learning process. ${ }^{23,24}$

Professionals with different academic levels accessed the modules of Portal do Zumbido and evaluated it, corroborating with the affirmation that the programs of telehealth can establish an important alternative of promotion of the continuous professional updating, thus, it can help on the reduction of educational deficits in Brazil (-Fig. 4). ${ }^{18,23-25}$

The entire content of Portal doZumbido was developed with the support of a professional designer; thus, it was possible to transmit the necessary information in a less exhaustive way, with the use of infographics. ${ }^{17}$

The Portal do Zumbido was divided into modules. The first module is characterized by the introduction to tinnitus. In this module, important concepts regarding the symptom (classification, cure), scientific articles dealing with the topic, and specific books of audiology were used, as well as other studies that also had as an objective the development of virtual platforms of information. $9,12,13,24$

The second module, "audiological diagnosis," contemplates the main procedures performed for the assessment of hearing and to detect the presence or absence of hearing loss. ${ }^{26}$ The importance of developing a module on this topic is due to the fact that tinnitus occurs as an isolated idiopathic symptom or related to any type of hearing loss. ${ }^{27}$ Tinnitus can cause physiological changes throughout the entire auditory pathway. In more than $50 \%$ of the cases, the symptom is a consequence of early cochlear lesions, such as sudden hearing loss, noise-induced acoustic trauma, presbiacusis or use of ototoxic drugs. ${ }^{28}$ Therefore, it is extremely important to perform the evaluation of auditory functions.

In addition, there are exams that early detect the hearing loss, since they evaluate an extended range of frequencies, which is not evaluated in conventional audiometry. Thus, the module "Complementary examinations," provides information regarding tinnitus and hearing loss to guide professionals that attend this population. ${ }^{26,29}$
One of the main reasons that encouraged the development of the present study was to address the intervention of patients with tinnitus. The following three modules, entitled "Fitting of hearing aids," "Fitting of Sound Generator" and "Counseling" address the main treatments that the speech therapist can offer to the subject with tinnitus, in view of the habituation and remission of the symptom. ${ }^{4,30-33}$ Therefore, questionnaires (THI, HHIA, HHIE) that help the speech therapists to understand both hearing loss and tinnitus have been available in these modules for download and printing. ${ }^{34}$ Providing scientific information about a specific content in audiology and providing resources for download and printing were also used by other researchers who developed virtual platforms. ${ }^{9,18,24}$

Concerning tinnitus subjects, the speech therapist should offer individualized care. Thus, during the whole process, from diagnosis to treatment, the speech therapist may find situations that compete with other professionals. In this sense, the module "Leading" discusses this topic. Therefore, studies reported the prevalence of $28 \%$ to $76 \%$ of tinnitus in subjects with temporomandibular disorders (TMD), in addition, it can be associated with changes of several etiologies, requiring the performance of professionals with different specialties to provide global care for the necessity of the subject. ${ }^{35-37}$

The last module, "Assessment," was composed of the MRS and forms approaches for theoretical content. The results were satisfactory for the 10 questions, demonstrating that the content presented by the Portal do Zumbido was positively absorbed by the participants ( - Fig. 4). These positive results corroborate with other studies that have analyzed the theoretical content. ${ }^{24,38}$

Question 7, with the lowest hit rate ("Why to perform the self-reported questionnaires?"), presented 9.3\% of incorrect answers since it can be justified by the fact that there is no standardization and consensus on the assessment methods of tinnitus due to its complexity, thus, not all professionals use self-assessment questionnaires in the clinical routine. ${ }^{4,28,39}$

In relation to the analysis of the motivational aspects of the portal through the MRS, ${ }^{18,24,25}$ it was possible to observe high satisfaction with the Portal do Zumbido since the participating professionals considered it impressive. ${ }^{40}$ The same was observed in the other study, which aim was to develop and analyze the effectiveness of a Hearing Health Training Program (Hearing aids) through interactive teleeducation. $^{13}$

Regarding the four domains analyzed ("organized," "easy to use," "stimulating" and "significant"), the scores varied from 22.8, 22.4, 22.5 and 22.2 (- Table 1), as a previous study that developed the FM System Portal and used the MRS with results that varied from $22.52,22.32,21.97$ and $21.45 .^{24}$

Therefore, it is important to reflect on the facilities promoted by telehealth, as well as its assistance in the continuing education of speech therapists, thus it is suggested that the Portal do Zumbido be continually updated due to the need to provide current scientific information to professionals working with this population. 


\section{Conclusions}

A virtual platform on tinnitus management in portal format was developed.

The Portal do Zumbido is available at zumbido.fob.usp.br.

The motivation of the participating professionals regarding Portal do Zumbido was satisfactory, and it was classified as impressive.

Access to the modules of Portal do Zumbido allowed the participants to absorb the proposed content.

\section{Funding}

This work was supported by the Coordination of Superior Level Staff Improvement (CAPES- Financing Code 001).

\section{Conflict of Interests}

The authors have no conflict of interests to declare.

\section{References}

1 Teixeira AR, Rosito LPS, Gonçalves AK, Nunes MGP, Dornelles S, Olchik MR. Tinnitus in elderly individuals: discomfort and impact in the quality of life. Int Arch Otorhinolaryngol 2017;21(01):66-71

2 Al-Swiahb J, Park SN. Characterization of tinnitus in different age groups: A retrospective review. Noise Health 2016;18(83): 214-219

3 Hoare DJ, Gander PE, Collins L, Smith S, Hall DA. Management of tinnitus in English NHS audiology departments: an evaluation of current practice. J Eval Clin Pract 2012;18(02):326-334

4 Tunkel DE, Bauer CA, Sun GH, et al. Clinical practice guideline: tinnitus. Otolaryngol Head Neck Surg 2014;151 (02):S1-S40

5 Langguth B, Elgoyhen AB, Cederroth CR. Therapeutic Approaches to the Treatment of Tinnitus. Annu Rev PharmacolToxicol 2019; 59:291-313

6 Tutaj L, Hoare DJ, Sereda M. Combined amplification and sound generation for tinnitus: A scoping review. EarHear 2018;39(03): 412-422

7 Esteves CC, Brandão FN, Siqueira CGA, Carvalho SAS. Audição, zumbido e qualidade de vida: um estudo piloto. Rev CEFAC 2012; 14(05):836-843

8 Pinto PCL, Sanchez TG, Tomita S. The impact of gender, age and hearing loss on tinnitus severity. RevBrasOtorrinolaringol (Engl Ed) 2010;76(01):18-24

9 Ferrari DV, Blasca WQ Bernardez-Braga GRA, Wen CL. Telessaúde: acesso à educação e assistência em audiologia. In: Bevilacqua MC, Martinez MA, Balleri AS, Pupo AC, Reis AC, Frota SM, ed. Saúde Auditiva no Brasil: políticas, serviços e sistemas. São José dos Campos: Pulso Editorial; 2010:189218

10 Paixão MP. Modelo de educação a distância em hanseníase voltado para a rede de detecção de casos e diagnóstico [thesis]. São Paulo (SP): Faculdade de Medicina, Universidade de São Paulo; 2008

11 Guitton MJ. Telemedicine in tinnitus: feasibility, advantages, limitations, and perspectives. ISRN Otolaryngol 2013; 2013:218265

12 Filatro A, Piconez SCB. Design instrucional contextualizado: planejamento, elaboração e avaliação de materiais didáticos para educação a distância [Internet]. 2004 Available at: http://www.abed. org.br/congresso2004/por/pdf/049-TC-B2.pdf. Acessed May 11, 2019

13 Blasca WQ Kuchar J, Pardo-Fanton CS, Ascencio ACS, Falsetti APM, Mondelli MFCG. Modelo de educação em saúde auditiva. Rev CEFAC 2014;16(01):23-30
14 Passos R, Moura M. Design da Informação na hipermídia. Infodesign 2007;4(02):19-27

15 Pettersson R. It depends: principles and guidelines. IIID Public Library. 4th ed. Wien:Austria; 2012 Available at: <http://www. iiid.net/PublicLibrary/Pettersson-Rune-ID-It-Depends.pdf >. Acessed May 11, 2019

16 De Souza JAC. Texto e discurso no infográfico de Divulgação Científica Midiática (DCM). Calidoscopio 2013;11(03): 229-240

17 Siricharoen WV. Infographics: the new communication tools in digital age. In: The international conference on e-technologies and business on the web (ebw2013). 2013:169174

18 Blasca WQ. Telessaúde: intercâmbio técnico científico entre centros de atendimento ao deficiente auditivo [thesis]. Bauru (SP)Faculdade de Odontologia de Bauru, Universidade de São Paulo2012

19 Rosa MRD, Almeida AAF, Pimenta F, Silva CG, Lima MAR, Diniz MFFM. Zumbido e ansiedade: umarevisão da literatura. Rev CEFAC 2012; 14:742-754

20 Strumila R, Lengvenytė A, Vainutienè V, Lesinskas E. The role of questioning environment, personality traits, depressive and anxiety symptoms in tinnitus severity perception. Psychiatr Q 2017; 88(04):865-877

21 Manganello JA, Gerstner G, Pergolino K, Graham Y, Strogatz D. Understanding digital technology access and use among New York state residents to enhance dissemination of health information. JMIR Public Health Surveill 2016;2(01):e9

22 Conselho Federal de Fonoaudiologia. Número de Fonoaudiólogos no Brasil por Conselho Regional [Internet] 2017. Available at: http://www.fonoaudiologia.org.br/cffa/index.php/numero-porregiao. Acessed May 11, 2019

23 Ascencio ACS. A teleducação interativa na capacitação de profissionais em saúde auditiva [dissertation]. Bauru (SP): Faculdade de Odontologia de Bauru, Universidade de São Paulo; 2012

24 Alves TKM. Portal Sistema FM: intercâmbio técnico científico entre profissionais que atuam com alunos usuários de Sistema FM [dissertation]. Bauru (SP): Faculdade de Odontologia de Bauru; Universidade de São Paulo; 2016

25 Picolini MM, Maximino LP. Programa de educação em síndromes genéticas: avaliação motivacional de um material educacional online. Rev CEFAC 2014;16(01):252-259

26 Boéchat EM, de Lemos PM, do Couto CM, Frizzo ACF, Scharlach RC, Anastasio ART. Tratado de audiologia. 2nd ed. Garulhos, SP: Editora Guanabara; 2015

27 Savage J, Waddell A. Tinnitus. BMJ Clin Evid 2014;2014:1-32

28 Langguth B, Kreuzer PM, Kleinjung T, De Ridder D. Tinnitus: causes and clinical management. Lancet Neurol 2013;12(09): 920-930

29 Chari DA, Limb CJ. Tinnitus. Med Clin North Am 2018;102(06): 1081-1093

30 dos Santos GM, Bento RF, de Medeiros IR, Oiticcica J, da Silva EC, Penteado $S$. The influence of sound generator associated with conventional amplification for tinnitus control: randomized blind clinical trial. Trends Hear 2014;18:1-9

31 Berberian AP, Ribas A, Imlau D, et al. Benefit of using the prosthesis with sound generators in individuals with tinnitus associated with mild to moderately severe hearing loss. Int Tinnitus J 2017;20(02):64-68

32 Park JM, Kim WJ, Ha JB, Han JJ, Park SY, Park SN. Effect of sound generator on tinnitus and hyperacusis. Acta Otolaryngol 2018; 138(02):135-139

33 Rocha AV, Mondelli MFCG. Sound generator associated with the counseling in the treatment of tinnitus: evaluation of the effectiveness. RevBrasOtorrinolaringol (Engl Ed) 2017;83(03):249-255

34 Suzuki FAB, Suzuki FA, Onishi ET, Penido NO. Psychoacoustic classification of persistent tinnitus. Rev Bras Otorrinolaringol (Engl Ed) 2018;84(05):583-590 
35 Almeida TAS, Samelli AG, Mecca FDN, de Martino E, Paulino AM. Sensação subjetiva do zumbido pré e pós intervenção nutricional em alterações metabólicas. Pro Fono 2009;21(04):291-296

36 Urban VM, Neppelenbroek KH, Pavan S, de Alencar Júnior FGP, Jorge JH, Almilhatti HJ. Associação entre otalgia, zumbido, vertigem e hipoacusia com desordens temporomandibulares. RGO (Porto Alegre) 2009;57:107-115

37 Ciminelli P, Machado S, Palmeira M, et al. Tinnitus: The Sound of Stress? Clin Pract Epidemiol Ment Health 2018;14:264-269
38 Paula Erika Alves F, Cunha F, Onishi ET, Branco-Barreiro FCA, Ganança FF. Tinnitus handicap inventory: adaptação cultural para o Português Brasileiro. Pro Fono 2005;17(03):303-310

39 Nascimento IP. Relação entre o Tinnitus Handicap Invetory, acufenometria e avaliação visual analógica na avaliação do zumbido [dissertation]. João Pessoa (PB): Universidade Federal da Paraíba;2015

40 Small RV, Arnone MP. Motivation mining: prospecting the web. Book Rep 1999;18:42-44 


\section{Appendix A - Questionnaire about the Theoretical Content}

1. What is tinnitus?

- An auditory system disease

- It is a symptom

- It is a cardiovascular disease

2. Why perform an audiological diagnosis in subjects with tinnitus complaints?

- Because the audiological diagnosis included a range of procedures that help in the understanding of tinnitus.

- Because the audiological diagnosis is the treatment for tinnitus.

- Because de audiological diagnosis includes complex procedures that presented the same information.

3. Why perform further tests on subjects with tinnitus complaints?

- Because the clinical protocol comprises further testing.

- Because wide information can be obtained for tinnitus and the auditory system.

- It is not necessary to perform further tests.

4. What is sound therapy?

- The only possible intervention for tinnitus.

- A possible intervention for tinnitus.

- A further diagnosis procedure.

5. From the alternatives below, what is used in sound therapy?

- Microphones and/or books.

- Ear mold and /or olives.

- Hearing aids and/ or sound generator.

6. Question related to hearing aids fitting in subjects with tinnitus complaints and hearing loss:

- Hearing aids fitting only provide better speech understanding due to amplification.

- Hearing aids fitting only provide better speech understanding and the ability of sound localization, however, there is no scientific evidence for the decrease in the perception of tinnitus.

- Hearing aids fitting can decrease the perception of tinnitus and improve the reaction for the symptom with the aid of a sound feedback.

7. Why perform the self-reported questionnaires?

- Due to the wide learning about tinnitus, hearing loss, and the handicap.

- Due to the wide learning about neural plasticity and cortical reorganization in the central auditory pathway.

- Due to the wide learning about the central nervous system.

8. What is a sound generator?

- An electronic sharing device

- A sound amplification device.

- A device that provides wide band noise or other types of noise.

9. Why is counseling relevant?

- Because the professional must know the theoretical characteristics of the complaint.

- Because counseling helps the subject with tinnitus to understand and accept the symptom.

- Because counseling is part of the audiological clinical protocol.

10. Why should speech therapists lead a patient with tinnitus complaints to other professionals?

- Because the audiological diagnosis does not help in understanding tinnitus.

- Because the speech therapist does not participate in the intervention of tinnitus.

- Because the speech therapist can understand the subject in a global way, improving his quality of life. 